\title{
Developing Classifications of Laryngeal Dysplasia: The Historical Basis
}

\author{
Henrik Hellquist · Alfio Ferlito · Antti A. Mäkitie - Lester D. R. Thompson • \\ Justin A. Bishop · Abbas Agaimy · Juan C. Hernandez-Prera • \\ Douglas R. Gnepp · Stefan M. Willems • Pieter J. Slootweg • \\ Alessandra Rinaldo
}

Received: March 19, 2020 / Published online: April 23, 2020

(C) The Author(s) 2020

\section{ABSTRACT}

During the last 60 years numerous significant attempts have been made to achieve a widely acceptable terminology and histological grading for laryngeal squamous intraepithelial lesions. While dysplasia was included in the

This article was written by members and invitees of the International Head and Neck Scientific Group (www. IHNSG.com).

Digital Features To view digital features for this article go to https://doi.org/10.6084/m9.figshare.12095979.

H. Hellquist ( $\square)$

Epigenetics and Human Disease Laboratory, Faro, Portugal

e-mail: henrikhellquist@gmail.com

H. Hellquist

Department of Biomedical Sciences and Medicine, Faro, Portugal

H. Hellquist

Centre of Biomedical Research (CBMR) and Algarve

Biomedical Center (ABC), Faro, Portugal

A. Ferlito

International Head and Neck Scientific Group,

Padua, Italy

A. A. Mäkitie

Department of Otorhinolaryngology Head and Neck

Surgery, University of Helsinki and Helsinki

University Hospital, Helsinki, Finland pathology of the uterine cervix already in 1953, the term dysplasia was accepted in laryngeal pathology first after the Toronto Centennial Conference on Laryngeal Cancer in 1974. In 1963 Kleinsasser proposed a three-tier classification, and in 1971 Kambic and Lenart proposed a four-tier classification. Since then, four editions of the World Health Organisation (WHO) classification have been proposed (1978, 1991, 2005 and 2017). Several terms such as squamous intraepithelial neoplasia (SIN) and laryngeal intraepithelial neoplasia (LIN) are now being abandoned and replaced by squamous intraepithelial lesions (SIL). The essential

\section{D. R. Thompson}

Department of Pathology, Southern California

Permanente Medical Group, Woodland Hills

Medical Center, Woodland Hills, CA, USA

\section{J. A. Bishop}

Department of Pathology, University of Texas

Southwestern Medical Center, Dallas, TX, USA

\section{A. Agaimy}

Institute of Pathology, University Hospital,

Friedrich-Alexander University Erlangen-Nürnberg, Erlangen, Germany

J. C. Hernandez-Prera

Department of Pathology, Moffitt Cancer Centre, Tampa, FL, USA

D. R. Gnepp

Department of Pathology, Alpert Medical School at Brown University, Providence, RI, USA 
change between the 2005 and 2017 WHO classifications is the attempt to induce a simplification from a four- to a two-tier system. The current WHO classification (2017) thus recommends the use of a two-tier system with reasonably clear histopathological criteria for the two groups: low-grade and high-grade dysplasia. Problems with interobserver variability apart, subjectivities and uncertainties remain, but to a lesser degree. Ongoing and additional molecular studies may help to clarify underlying events that will increase our understanding and possibly can facilitate our attempts to obtain an even better classification. The classification needs to be easier for the general pathologist to perform and easier for the clinician to interpret. These two objectives are equally important to provide each patient the best personalised treatment available for squamous intraepithelial lesions.

Keywords: Laryngeal dysplasia; Laryngeal precancerous lesions; Laryngeal precursor lesions; WHO classification

\section{Key Summary Points}

For more than 60 years pathologists and otolaryngologists worldwide have made serious efforts to achieve a histological grading system of squamous intraepithelial lesions.

The 1974 Toronto Centennial Conference on Laryngeal Cancer was an important kick-off point.

\footnotetext{
S. M. Willems

Department of Pathology and Medical Biology, University Medical Center Groningen, Groningen, The Netherlands

P. J. Slootweg

Department of Pathology, Radboud University

Nijmegen Medical Center, Nijmegen,

The Netherlands

A. Rinaldo

University of Udine School of Medicine, Udine, Italy
}

There have now been four editions of WHO classification proposals for these lesions (1978, 1991, 2005 and 2017) but uncertainties and controversies remain, albeit to a lesser degree than before.

Several terms, such as squamous intraepithelial neoplasia (SIN) and laryngeal intraepithelial neoplasia (LIN), are, after the WHO classification (2017), slowly fading away in the developmental process of the classification and giving room for "squamous intraepithelial lesions" (SIL).

The Ljubljana classification with its amendment of 2014 has not gained a wider acceptance in routine histopathology. It has contributed considerably to the existing WHO suggestion of a two-tier system, i.e., lowand high-grade lesions. Despite several potential benefits of a two-tier system, wide endorsement of the classification remains to be achieved.

During the last 60 years numerous distinguished pathologists and otolaryngologistshead and neck surgeons have made significant attempts to achieve a widely acceptable terminology and histological grading for laryngeal squamous intraepithelial lesions. The prime objective of any proposed grading system has been to obtain a readily reproducible system that is able to reliably predict the biological behaviour and prognosis and thus guide appropriate therapy. Accordingly, the grading system should have defined morphological criteria with an interobserver variability as minimal as possible. The terminology in use has to be simple or self-explaining and familiar to clinicians for the grading system to act as a useful guidance for clinical management. The system should provide a reasonably accurate prediction of the risk of recurrence, risk for progression and development of frank malignancy. As controversies and uncertainties remain to this day, further improvement in the 
grading of squamous intraepithelial lesions, possibly with use of new molecular techniques, is highly desirable and of utmost importance for the clinical management and prognosis.

Already in 1952, a long time before the term dysplasia was acknowledged and established in laryngeal pathology, Stout and others drew attention to the existence of laryngeal squamous cell carcinoma in situ [1-3]. Other early studies were performed to distinguish between various proliferative epithelial laryngeal lesions and to assess the frequency with which they develop into invasive carcinoma [4-6]. In 1963 Kleinsasser, an eminent European laryngologist of the last century, proposed a three-tier classification for proliferative squamous cell lesions that was based primarily on nuclear atypia. Group I consisted of simple hyperplasia, group II of restless hyperplasia and group III of carcinoma in situ [7]. In 1971 Kambič and Lenart proposed a four-tier classification mainly based on hyperplasia, either simple, abnormal or atypical hyperplasia, and carcinoma in situ [8]. Neither of these two proposals gained any wider acceptance in the Anglo-Saxon medical world, possibly because they were published in German and French and in clinical head and neck journals, not pathology journals. While dysplasia was included in the pathology of the uterine cervix already in 1953 [9], it took 2 more decades before the term dysplasia was introduced in laryngeal pathology at the Workshop at the Centennial Conference on Laryngeal Cancer held in Toronto in 1974 [10]. The nomenclature recommended by attending prominent pathologists and otolaryngologists (such as Batsakis, Bauer, Fechner, Fisher, Friedmann and Miller, to name just a few) was in fact rather closely consistent with that of Kleinsasser. The 1974 proposal was further refined over the years and constituted the foundation for both the first (1978) and second (1991) edition of World Health Organisation (WHO) histological classifications, both of which endorsed laryngeal dysplasia $[11,12]$. The second WHO classification recognised mild, moderate and severe dysplasia, while carcinoma in situ was discussed separately.

The Toronto Conference in 1974 initiated many clinicopathological studies on laryngeal proliferative epithelial lesions in efforts to obtain increased knowledge and create an improved grading system. Many of the investigations also included the use of different ancillary techniques available at that time, such as DNA analysis, quantitative morphometry, immunohistochemistry and scanning electron microscopy, among others [13-41]. The term squamous intraepithelial neoplasia (SIN) was used for laryngeal precursor lesions by Friedmann and Osborn in 1976 [13], and 10 years later Crissman and $\mathrm{Fu}$ opted for intraepithelial neoplasia of the larynx [42]. In addition, Friedmann and Ferlito used laryngeal intraepithelial neoplasia (LIN). An attempt to reconcile different schemes showed LIN I is regarded the equivalent of mild dysplasia, LIN II of moderate dysplasia and LIN III of severe dysplasia and carcinoma in situ [36]. Parts of the SIN and LIN proposals appeared in the third (2005) and fourth (2017) editions of the WHO classifications [43, 44]. The publication in 1995 of the Ljubljana experience by Kambič and Gale was a strong revival of the old 1971 Kambič and Lenart classification. This constituted a major new foundation for several studies and became known as the Ljubljana classification [40, 45]. Well before the third edition of the WHO classification an excellent review was written by Wenig in 2002 and further updated in 2017. It comprised not only laryngeal lesions but also those of the entire upper respiratory tract and pinpointed basic definitions of the terminology and the histological and clinical differences between severe dysplasia and carcinoma in situ. In addition, several other important issues were included that still, almost 20 years later, are most appropriate and valid, although still unsolved $[46,47]$. It is noteworthy that similar efforts undertaken for squamous precursor lesions in other head and neck organs had certain success. The dysplasia concept of mild, moderate and severe grading was recommended for oral precancerous lesions and is widely used (see Warnakulasuriya et al. for a review) [48] but a uniform/standard histopathological terminology for proliferating lesions of stratified squamous epithelia in other head and neck organs has not yet materialised. It is also important to emphasise that laryngeal dysplasia 
is histologically different from uterine cervical dysplasia because of the presence of epithelial thickening, surface maturation/keratinisation and dyskeratosis. The classic carcinoma in situ with full epithelial replacement is rare in the larynx. This phenomenon was described by Hellquist et al. in 1982 [20], Crissman in 1982 [49], Crissman et al. in 1988 [50] and Crissman and Zarbo in 1989 [29]. The studies in 1982 and 1989 also demonstrated that severe keratinising dysplasia carried a risk of greater frequency of progression to squamous cell carcinoma than that of full thickness carcinoma in situ $[20,29]$.

In an attempt to clarify and reduce the controversy that existed in the 1990s after the publication of the second WHO classification, the third WHO Blue Book on Pathology and Genetics of Head and Neck Tumours was published in 2005 [51]. It presented three oftenused schemes for classifying laryngeal precursor lesions (WHO, SIN and Ljubljana). The schemes included: (1) a five-grade dysplasia system featuring squamous cell hyperplasia, mild, moderate and severe dysplasia, and carcinoma in situ; (2) a three-grade SIN featuring mild dysplasia (basal/parabasal hyperplasia), moderate and severe dysplasia (severe dysplasia and carcinoma in situ) and (3) a four-grade Ljubljana classification featuring squamous hyperplasia, basal/parabasal hyperplasia, atypical hyperplasia and carcinoma in situ [44]. However, studies assessing the interobserver variability did not show superiority of any of the three classification systems [52-54].

Problems with interobserver variability apart, subjectivities and uncertainties remained after the 2005 WHO recommendations. Further studies took place to refine the exact morphological criteria for histological grading and revise existing classifications, and more molecular studies were introduced. Before an amended Ljubljana classification was proposed in 2014 [55], several updates and reviews were undertaken [56-58]. An interesting approach was presented in 2012 by Ferlito et al. who placed pathological changes into two groups based on their clinical relevance with regard to treatment. The first group would generally not require any additional treatment or close follow-up (briefly, metaplastic, hyperplastic and keratotic lesions) while the second group would demand either local therapy or close follow-up to monitor any progression to a more aggressive pathology (briefly, dysplasia and carcinoma in situ) [59]. This system is very attractive, as most two-tier systems are, but they all share the shortcoming of artificial lumping of those lesions with moderate histological dysplasia into either the low- or high-grade category. This is simply true as moderately dysplastic lesions do occur along the continuum of preneoplastic changes. For many if not most pathologists, albeit following recommended criteria for architectural disturbances and cytological atypia, moderate dysplasia is often for those dysplastic lesions that do not fit either end of the scale, thus falling in between. This description of moderate dysplasia, although not scientifically attractive, and possibly not valid, represents a useful applied approach to routine histopathological reporting. Several proliferative laryngeal squamous lesions are reversible and do not progress, and some are not neoplastic processes per se. The term precursor lesion is used in the latest 2017 WHO classification for dysplasia of any grade. However, distinction among proliferation, neoplasia and/ or neoplasm is, although necessary, not always possible or reproducible. Therefore, terms such as laryngeal intraepithelial neoplasia (LIN), intraepithelial neoplasia of the larynx and squamous intraepithelial neoplasia (SIN) are not appropriate. The term squamous intraepithelial lesion (SIL) is much preferred, and after the amendment of the Ljubljana classification in 2014, the term SIL became firmly established and accepted by most as the best term for proliferating intraepithelial laryngeal lesions [55]. Further studies contributing to the updates eventually led to the new WHO classification published in the 2017 [44, 60, 61].

The current WHO classification (2017) recommends the use of a two-grade system, following a trend in other organs, such as oesophageal dysplasia and dysplasia of intestinal adenomas. Reasonably clear histopathological criteria are given for defining the two groups: low-grade and high-grade dysplasia. If a three-tier system is preferred, then high-grade dysplasia and carcinoma in situ should be 
separated for management considerations [44]. For details, the interested reader should consult Chapter 3, Tables 3.02 and 3.03, in the 2017 WHO classification (although these two tables are not entirely in agreement) [62]. However, despite the benefits of the 2017 WHO classification, wide endorsement of the classification remains to be achieved. Some prefer to state that laryngeal dysplasia is now separated into only low- and high-grade categories [63], whilst others have a more cautious approach partially adopting histological criteria for a dysplasia system compared with the 2017 WHO classification. For example, Wenig subdivided dysplasia into classic or non-keratinising, basalcell type and keratinising spinous type. He also emphasises the importance of an increased number of dyskeratotic cells appearing throughout the entire epithelium as indicative of the presence of significant dysplasia [47]. Others regard the 2017 WHO classification as a potential source of disunity regarding the number of grades and morphological criteria and pointing out that the system creates difficulties in providing reliable diagnosis of laryngeal precursor lesions [64]. Further correspondence on this issue can be read in the recent Letters to the Editor of The Laryngoscope $[62,65]$. Importantly, it should be noted the demographics and management options for laryngeal dysplasia are changing over time and vary within countries and institutions [66]. Therefore, it has been proposed that laryngeal lesions with dysplastic alterations should be discussed in a multidisciplinary setting to determine treatment and follow-up strategies [67]. These discussions are particularly important when a new system is proposed (Table 1).

Some pathologists currently grade laryngeal dysplasias as mild, moderate or severe while others prefer to use the two-tier system including low- and high-grade dysplasia, with the high-grade entity encompassing moderate and severe dysplasia and carcinoma in situ. It remains critical to categorise various laryngeal epithelial abnormalities according to their individual risk of progressing to an invasive neoplasm. Severe dysplasia and carcinoma in situ (LIN III) and to a lesser extent mild and moderate dysplasia (LIN I and LIN II) do carry this risk. On the contrary, laryngeal aberrations of squamous metaplasia, squamous cell hyperplasia, pseudoepitheliomatous hyperplasia and simple keratosis without atypia lack this potential. These abnormalities in the surface epithelium have been erroneously considered premalignant, but they have a favourable prognosis and therefore do not warrant frequent follow-up [59]. Severe dysplasia (but not moderate dysplasia) carries the same high risk

Table 1 Nomenclature for the development of laryngeal dysplasia

\begin{tabular}{llll}
\hline Nomenclature & Author(s) & Year & References \\
\hline Intraepithelial carcinoma & Altmann et al. & 1952 & {$[1]$} \\
Carcinoma in situ & Reagan et al. & 1953 & {$[9]$} \\
Proliferative squamous cell lesions & Kleinsasser & 1963 & {$[7]$} \\
Carcinoma in situ & Miller and Batsakis & 1974 & {$[10]$} \\
Squamous intraepithelial neoplasia (SIN) & Friedmann and Osborn & 1976 & {$[13]$} \\
Dysplasia, carcinoma in situ & WHO classification & 1978 & {$[11]$} \\
Intraepithelial neoplasia of the larynx & Crissman and Fu & 1986 & {$[42]$} \\
Laryngeal intraepithelial neoplasia (LIN) & Friedmann and Ferlito & 1988 & {$[36]$} \\
Squamous intraepithelial lesion (SIL) & Gale et al. & 2014 & {$[55]$} \\
Dysplasia: low-grade, high-grade & WHO classification & 2017 & {$[44]$} \\
\hline
\end{tabular}


for developing invasive carcinoma as carcinoma in situ and these entities are therefore grouped together for clinical purposes.

The use of immunohistochemistry and other biomarkers to improve and support the histological assessment and prediction of the progression of SILs and/or risk for development of cancer has virtually no practical value. A more recent study used cytokeratin 19 and concluded reduced inter- and intra-examiner variability [68]. This study was however performed on dysplastic lesions of the upper aerodigestive tract as a whole and on non-keratinising epithelia only. Therefore, it is not specific or particularly valid for laryngeal dysplasia, as most of laryngeal SILs have keratinising epithelium. Another immunohistochemical investigation of laryngeal precancerous lesions investigated the role of NANOG expression. The human NANOG protein, encoded by the NANOG1 gene, is a transcriptional factor that is involved in the maintenance of pluripotency in embryonic stem cells. The study showed that strong NANOG protein expression had a strong association with risk for development of invasive laryngeal carcinoma [69]. Another most interesting and promising immunohistochemical study on precancerous laryngeal lesions analysed the expression of CTTN and FAK (the genes CTTN, cortactin, and FAK, focal adhesion kinase, are both known to induce an aggressive behaviour in various cancers) in a cohort of 109 patients. The study concluded that both CTTN and FAK are powerful predictors for risk of recurrence and development into invasive carcinoma and to a degree that is considerably superior to conventional histological grading [70]. Recently, the same group also reported a combined immunohistochemical and molecular study (real-time PCR) on laryngeal precancerous lesions that is equally interesting. The investigations concluded that SOX2 gene amplification $(p=0.046)$ and SOX2 protein expression $(p<0.001)$ but not the histological grading ( $p=0.432$ ) were significantly associated with increased risk for laryngeal carcinoma [71]. The use of immunohistochemical identification of SOX2 may develop into a very practical and possibly reliable ancillary technique to the histological assessment of laryngeal squamous intraepithelial lesions. Also imaging examination techniques have been tested in attempts to estimate the risks for progression of different types of laryngeal dysplasia. One study using secondary analysis of data from meta-analyses and randomised trials concluded that narrowband imaging (NBI) is preferred over conventional white light imaging (WLI) and describes the need for NBI in the follow-up of patients with laryngeal dysplasia [72].

Most molecular/genetic studies have been performed on invasive laryngeal carcinoma, and often on head and neck squamous cell carcinomas in general, as well as in relation to the role of human papillomavirus (HPV) status (e.g., [73-77]). Only a few molecular/genetic studies have been performed on SILs. Mutational profiling in laryngeal dysplasia has been one approach. A study analysed 66 dysplastic lesions ( 24 progressing lesions and 42 non-progressing lesions) and 24 invasive carcinomas using targeting next-generation sequencing and revealed non-synchronous mutations in six different genes (PIK3CA, FGFR3, TP53, LAK3, $M E T, F B X W 7$ ). Mutations in PIK3CA and FGFR3 were seen in progressing dysplastic lesions and invasive carcinomas but not in non-progressing dysplastic lesions. JAK3, MET and FBXW7 showed mutations in non-progressing dysplastic lesions but not in invasive carcinomas or progressing dysplastic lesions. The authors conclude that mutational profiling may be of value in the early detection of patients at risk of progression [78]. A recent study investigated a possible association between the expression of MAGE-A in laryngeal (and oral) leukoplakia and malignant transformation to squamous cell carcinoma [79]. MAGE-A, the melanoma-associated antigen $\mathrm{A}$, is expressed in laryngeal and oral squamous cell carcinomas but is completely absent in healthy mucosal tissues $[79,80]$. In the study by Baran et al. analyses were performed using both immunohistochemistry and real time RT-PCR. Their cohorts consisted of 91 oral and laryngeal leukoplakia lesions that developed into squamous cell carcinoma (5-year follow-up), 114 that did not and 40 healthy mucosal samples. There was a significant risk of malignant transformation in leukoplakia lesions with immunohistochemical 
expression of MAGE-A $(p<0.001)$ and also statistically significant with real-time RT-PCR (MAGE-A3/6, $p=0.001$ and MAGE-A4, $p=0.002$ ). Interestingly, there was no significant association between MAGE-A expression and the histological grade of dysplasia (low or high grade). The authors conclude that the MAGE-A expression profile can be useful in predicting the risk of malignant transformation and therefore potentially a valuable ancillary technique to conventional histopathology [79].

In summary, the essential change between the 2005 and 2017 WHO classifications is the attempt to induce a simplification from a fourto a two-tier system by the unification into high-grade dysplasia of former moderate dysplasia, severe dysplasia and carcinoma in situ. One major problem is the persisting ambiguity in distinguishing low-grade dysplasia from basal/parabasal cell hyperplasia. Furthermore, it remains to be discussed how the pathologist should interpret lesions previously classified in the spectrum of moderate dysplasia. Do they all really belong to the category of high-grade dysplasia? Ongoing and additional studies may help to clarify underlying events that will increase our understanding and possibly can facilitate our attempts to obtain an even better classification. The classification needs to be easier for the practising general pathologist to perform and easier for the clinician to interpret. Both these two objectives are equally important to provide each patient the best personalised treatment available for squamous intraepithelial lesions. Integration of molecular and other biomarkers in future classification schemes might positively enhance their predictive value.

\section{ACKNOWLEDGEMENTS}

Funding. No funding or sponsorship was received for this study or publication of this article.

Authorship. All named authors meet the International Committee of Medical Journal Editors (ICMJE) criteria for authorship for this article, take responsibility for the integrity of the work as a whole and have given their approval for this version to be published.

Disclosures. Henrik Hellquist, Antti A. Mäkitie, Lester D.R. Thompson, Justin A. Bishop, Abbas Agaimy, Juan C. Hernandez-Prera, Douglas R. Gnepp, Stefan M. Willems and Pieter J. Slootweg have nothing to disclose. Alfio Ferlito and Alessandra Rinaldo are both editorial board members for Advances in Therapy but otherwise have nothing relevant to disclose.

Compliance with Ethics Guidelines. This article is based on previously conducted studies and does not contain any studies with human participants or animals performed by any of the authors.

Data Availability. The datasets generated during and/or analyzed during the current study are available from the corresponding author on reasonable request.

Open Access. This article is licensed under a Creative Commons Attribution-NonCommercial 4.0 International License, which permits any non-commercial use, sharing, adaptation, distribution and reproduction in any medium or format, as long as you give appropriate credit to the original author(s) and the source, provide a link to the Creative Commons licence, and indicate if changes were made. The images or other third party material in this article are included in the article's Creative Commons licence, unless indicated otherwise in a credit line to the material. If material is not included in the article's Creative Commons licence and your intended use is not permitted by statutory regulation or exceeds the permitted use, you will need to obtain permission directly from the copyright holder. To view a copy of this licence, visit http:// creativecommons.org/licenses/by-nc/4.0/.

\section{REFERENCES}

1. Altmann F, Ginsberg I, Stout AP. Intraepithelial carcinoma (cancer in situ) of the larynx. AMA Arch Otolaryngol. 1952;56:121-33. 
2. Stout AP. Intramucosal epithelioma of the larynx. Am J Rontgenol Radium Ther Nucl Med. 1953;69: $1-13$.

3. Stout AP. Laryngeal carcinoma in situ. Ariz Med. 1960;17:201-2.

4. Putney FJ, O'Keefe JJ. Clinical significance of keratosis of the larynx as a premalignant lesion. Ann Otol Rhinol Laryngol. 1953;62:348-57.

5. Gabriel CE, Jones DG. Hyperkeratosis of the larynx. J Laryngol Otol. 1962;76:947-57.

6. Norris CM, Peale AR. Keratosis of the larynx. J Laryngol Otol. 1963;77:635-47.

7. Kleinsasser O. The classification and differential diagnosis of epithelial hyperplasia of the laryngeal mucosa on the basis of histomorphological features. II. Z Laryngol Rhinol Otol. 1963;42:339-62 (German).

8. Kambic V, Lenart I. Our classification of hyperplasia of the laryngeal epithelium from the prognostic point of view. J Fr Otorhinolaryngol Audiophonol Chir Maxillofac. 1971;20:1145-1150 (French).

9. Reagan JW, Seidemann IL, Saracusa Y. The cellular morphology of carcinoma in situ and dysplasia or atypical hyperplasia of the uterine cervix. Cancer. 1953;6:224-34.

10. Miller AH, Batsakis JG. Premalignant laryngeal lesions, carcinoma in situ, superficial carcinomadefinition and management. Centennial conference on laryngeal cancer. Can J Otolaryngol. 1974;3:515-75.

11. Shanmugaratnam K, Sobin LH, Pathologists in 10 countries. Histological typing of upper respiratory tract tumours. Geneva: World Health Organization; 1978.

12. Shanmugaratnam $\mathrm{K}$, Sobin LH, Pathologists in 8 countries. Histological typing of tumours of the upper respiratory tract and ear. 2nd ed. Berlin: World Health Organization. Springer-Verlag; 1991.

13. Friedmann I, Osborn DA. The larynx. In: Symmers WSTC, editor. Systemic pathology. 3rd ed. Edinburgh: Churchill Livingstone; 1976.

14. Kambič V. Macro-microscopical findings and prognosis of hyperplastic aberrations of the laryngeal mucosal membrane. Acta Otolaryngol Suppl. 1977;344:19-211.

15. Ferlito A. Carcinoma in situ of the larynx-an unsatisfactory diagnosis. Clin Otolaryngol Allied Sci. 1977;2:292.
16. Crissman JD. Laryngeal keratosis and subsequent carcinoma. Head Neck Surg. 1979;1:386-91.

17. Henry RC. The transformation of laryngeal leucoplakia to cancer. J Laryngol Otol. 1979;93: 447-59.

18. Ferlito A, Polidoro F, Rossi M. Pathological basis and clinical aspects of treatment in carcinoma-insitu of the larynx. J Laryngol Otol. 1981;95:141-54.

19. Hellquist H, Olofsson J. Photometric evaluation of laryngeal epithelium exhibiting hyperplasia, keratosis and moderate dysplasia. Acta Otolaryngol. 1981;92:157-65.

20. Hellquist H, Lundgren J, Olofsson J. Hyperplasia, keratosis, dysplasia and carcinoma in situ of the vocal cords-a follow-up study. Clin Otolaryngol Allied Sci. 1982;7:11-27.

21. Lundgren J, Olofsson J, Hellquist H, Gröntoft O. Scanning electron microscopy of vocal cord hyperplasia, keratosis, papillomatosis, dysplasia and carcinoma. Acta Otolaryngol. 1983;96:315-27.

22. Goodman ML. Keratosis of the larynx. Otolaryngol Clin North Am. 1984;17:179-83.

23. Kaplan MJ, Mills SE, Rice RH, Johns ME. Involucrin in laryngeal dysplasia. A marker for differentiation. Arch Otolaryngol. 1984;110:713-6.

24. Olde Kalter P, Lubsen H, Delemarre JF, Alons CL, Veldhuizen RW, Meyer CJ, Snow GB. Quantitative morphometry of squamous cell hyperplasia of the larynx. J Clin Pathol. 1985;38:489-95.

25. Kambič V, Gale N. Significance of keratosis and dyskeratosis for classifying hyperplastic aberrations of laryngeal mucosa. Am J Otolaryngol. 1986;7: 323-33 (Pt 1:311-352).

26. Kalter PO, Lubsen H, Delemarre JF, Snow GB. Squamous cell hyperplasia of the larynx (a clinical follow-up study). J Laryngol Otol. 1987;101:579-88.

27. Crissman JD, Gnepp DR, Goodman ML, Hellquist $\mathrm{H}$, Johns ME. Preinvasive lesions of the upper aerodigestive tract: histologic definitions and clinical implications. Pathol Annu. 1987; part 1, 311-352.

28. Hellquist HB, Olofsson J. Expression of low molecular weight cytokeratin proteins in laryngeal dysplasia. APMIS. 1988;96:971-8.

29. Crissman JD, Zarbo RJ. Dysplasia, in situ carcinoma, and progression to invasive squamous cell carcinoma of the upper aerodigestive tract. Am J Surg Pathol. 1989;13(Suppl 1):5-16. 
30. Miyaguchi M, Olofsson J, Hellquist H. Expression of epidermal growth factor receptor in laryngeal dysplasia and carcinoma. Acta Otolaryngol. 1990;110: 309-13.

31. Crissman JD, Zarbo RJ. Quantification of DNA ploidy in squamous intraepithelial neoplasia of the laryngeal glottis. Arch Otolaryngol Head Neck Surg. 1991;117:182-8.

32. Fechner RE, Mills SE. Premalignant lesions of the larynx. In: Silver C, editor. The larynx. Philadelphia: Saunders; 1991. p. 2-5.

33. Munck-Wikland E, Kuylenstierna R, Lindholm J, Auer G. Image cytometry DNA analysis of dysplastic squamous epithelial lesions in the larynx. Anticancer Res. 1991;11:597-600.

34. Bouquot JE, Gnepp DR. Laryngeal precancer: a review of the literature, commentary, and comparison with oral leukoplakia. Head Neck. 1991;13: 488-97.

35. Resta L, Colucci GA, Troia M, Russo S, Vacca E, Pesce DV. Laryngeal intraepithelial neoplasia (LIN). An analytical morphometric approach. Pathol Res Pract. 1992;188:517-23.

36. Friedmann I, Ferlto A. Granulomas and neoplasms of the larynx. Edinburgh: Churchill Livingstone; 1988. p. $111-122$.

37. Friedmann I. Precursors of squamous cell carcinoma. In: Ferlito A, editor. Surgical pathology of laryngeal neoplasms. London: Chapman and Hall; 1996. p. 107-122.

38. Cör A, Gale N, Kambic V. Quantitative pathology of laryngeal epithelial hyperplastic lesions. Acta Otolaryngol. 1997;527(Suppl):57-61.

39. Gale N, Zidar N, Kambic V, Poljak M, Cör A. Epidermal growth factor receptor, c-erbB-2 and p53 overexpression in epithelial hyperplastic lesions of the larynx. Acta Otolaryngol Suppl. 1997;527: 105-10.

40. Gale N, Kambič V, Michaels L, Cardesa A, Hellquist H, Zidar N, Poljak M. The Ljubljana classification: a practical strategy for the diagnosis of laryngeal precancerous lesions. Adv Anat Pathol. 2000;7: 240-51.

41. McLaren KM, Burnett RA, Goodland JR, Howatson SR, Lang S, Lee FD, et al. The Scottish Pathology Consistency Group. Histopathology. 2000;37: 460-3.

42. Crissman JD, Fu YS. Intraepithelial neoplasia of the larynx. A clinicopathologic study of six cases with
DNA analysis. Arch Otolaryngol Head Neck Surg. 1986;112:522-8.

43. Gale N, Pilch BZ, Sidransky D, Westra WH, Califano J. Epithelial precursor lesions. In: Barnes L, Eveson JW, Reichart P, Sidransky D, editors. Pathology and genetics head and neck tumours WHO classification of tumours. Lyon: IARC Press; 2005. p. 140-143.

44. Gale N, Hille J, Jordan RC, Nadal A, Williams MD. Precursor lesions. Dysplasia. In: El-Naggar AK, Chan JKC, Grandis JR, Takata T, Slootweg PJ, editors. WHO classification of head and neck tumours. Lyon: IARC; 2017. p. 91-93.

45. Kambič V, Gale N. Epithelial hyperplastic lesions of the larynx. Amsterdam: Elsevier; 1995. p. 1-265.

46. Wenig BM. Squamous cell carcinoma of the upper aerodigestive tract: precursors and problematic variants. Mod Pathol. 2002;15:229-54.

47. Wenig BM. Squamous cell carcinoma of the upper aerodigestive tract: dysplasia and select variants. Mod Pathol. 2017;30:S112-S11818.

48. Warnakulasuriya S, Reibel J, Bouquot J, Dabelsteen E. Oral epithelial dysplasia classification systems: predictive value, utility, weaknesses and scope for improvement. J Oral Pathol Med. 2008;37:127-33.

49. Crissman JD. Laryngeal keratosis preceding laryngeal carcinoma. A report of four cases. Arch Otolaryngol. 1982;108:445-58.

50. Crissman JD, Zarbo RJ, Drozdowicz S, Jacobs J, Ahmad K, Weaver A. Carcinoma in situ and microinvasive squamous carcinoma of the laryngeal glottis. Arch Otolaryngol Head Neck Surg. 1988;114:299-307.

51. Barnes L, Eveson JW, Reichart P, Sidransky D, editors. Pathology and genetics head and neck tumours. WHO classification of tumours. Lyon: IARC Press; 2005.

52. Eversole LR. Dysplasia of the upper aerodigestive tract squamous epithelium. Head Neck Pathol. 2009;3:63-8.

53. Sarioglu S, Cakalagaoglu F, Elagoz S, Han U, Etit D, Hucumenoglu S, et al. Inter-observer agreement in laryngeal pre-neoplastic lesions. Head Neck Pathol. 2010;4:276-80.

54. Fleskens SA, Bergshoeff VE, Voogd AC, van Velthuysen ML, Bot FJ, Speel EJ, et al. Interobserver variability of laryngeal mucosal premalignant lesions: a histopathological evaluation. Mod Pathol. 2011;24:892-8. 
55. Gale N, Blagus R, El-Mofty SK, Helliwell T, Prasad MI, Sandison A, et al. Evaluation of a new grading system for laryngeal squamous intraepithelial lesions-a proposed unified classification. Histopathology. 2014;65:456-64.

56. Gale N, Michaels L, Luzar B, Poljak M, Zidar N, Fishinger J, Cardesa A. Current review on squamous intraepithelial lesions of the larynx. Histopathology. 2009;54:639-56.

57. Weller MD, Nankivell PC, McConkey C, Paleri V, Mehamma HM. The risk and interval to malignancy of patients with laryngeal dysplasia: a systematic review of case series and meta-analysis. Clin Otolaryngol. 2010;35:364-72.

58. Gale N, Zidar N, Poljak M, Cardesa A. Current views and perspective on classification of squamous intraepithelial lesions of the head and neck. Head Neck Pathol. 2014;8:16-23.

59. Ferlito A, Devaney KO, Woolgar JA, Slootweg PJ, Paleri V, Takes RP, et al. Squamous epithelial changes of the larynx: diagnosis and therapy. Head Neck. 2012;34:1810-6.

60. van Hulst AM, Kroon W, van der Linden ES, Nagtzaam L, Ottenhof SR, Wegner I, Gunning AC, Grolman W, Braunius W. Grade of dysplasia and malignant transformation in adults with premalignant laryngeal lesions. Head Neck. 2016;28(Suppl 1):E2284-2290.

61. Gale N, Gnepp DR, Poljak M, Strojan P, Cardesa A, Helliwell T, Sifrer R, Volavšek M, Sandison A, Zidar N. Laryngeal squamous intraepithelial lesions: an updated review on etiology, classification, molecular changes, and treatment. Adv Anat Pathol. 2016;23:84-91.

62. Gale N, Hille J, Jordan RC, Nadal A, Williams MD. Regarding laryngeal precursor lesions: interrater and intrarater reliability of histopathological assessment. Letter to the editor. Laryngoscope. 2019;129:E91-E9292.

63. Thompson LD. Laryngeal dysplasia, squamous cell carcinoma, and variants. Surg Pathol Clin. 2017;10: 15-33.

64. Mehlum CS, Larsen SR, Kiss K, Groentved AM, Kjaergaard T, Möller S, Godballe C. Laryngeal precursor lesions: interrater and intrarater reliability of histopathological assessment. Laryngoscope. 2018;128:2375-9.

65. Mehlum CS, Groentved AM, Godballe C, Rosenkilde Larsen S, Kiss K, et al. In response to Laryngeal precursor lesions: Interrater and intrarater reliability of histopathological assessment. Letter to the editor. Laryngoscope. 2019;129:E93.
66. Karatayli-Ozgursoy S, Pacheco-Lopez P, Hillel AT, Best SR, Bishop JA, Akst LM. Laryngeal dysplasia, demographics, and treatment: a single-institution, 20-year review. JAMA Otolaryngol Head Neck Surg. 2015;141:313-8.

67. Mehanna H, Paleri V, Robson A, Wight R, Helliwell T. Consensus statement by otorhinolaryngologists and pathologists on the diagnosis and management of laryngeal dysplasia. Clin Otolaryngol. 2010;35: 170-6.

68. Safadi RA, AlRomaizan A, Alshagroud RS, Divakar DD, Alshieban S. Cytokeratin 19 immunostain reduces variability in grading epithelial dysplasia of the non-keratinized upper aerodigestive tract mucosa. Head Neck Pathol. 2019;14:183-91.

69. Rodrigo JP, Villaronga MA, Menéndez ST, HermidaPrado F, Quer M, Vilaseca I, et al. A novel role for NANOG as an early cancer risk marker in patients with laryngeal precancerous lesions. Sci Rep. 2017;7:11110.

70. Villaronga MÁ, Hermida-Prado F, Granda-Díaz R, Menéndez ST, Álvarez-Teijeiro S, Quer $\mathrm{M}$, et al. Immunohistochemical expression of cortactin and focal adhesion kinase predicts recurrence risk and laryngeal cancer risk beyond histologic grading. Cancer Epidemiol Biomarkers Prev. 2018;27: 805-13.

71. Granda-Díaz R, Menéndez ST, Pedregal Mallo D, Hermida-Prado F, Rodríguez R, Suárez-Fernández L, et al. The novel role of SOX2 as an early predictor of cancer risk in patients with laryngeal precancerous lesions. Cancers (Basel). 2019;11:286.

72. Paleri V, Sawant R, Mehanna H, Ainsworth H, Stocken D. Laryngeal dysplasia and narrow band imaging: secondary analysis of published data supports the role in patient follow-up. Clin Otolaryngol. 2018;43:1439-42.

73. Bishop JA, Ma XJ, Wang H, Luo Y, Illei PB, Begum S, et al. Detection of transcriptionally active high-risk HPV in patients with head and neck squamous cell carcinoma as visualized by a novel E6/E7 mRNA in situ hybridization method. Am J Surg Pathol. 2012;36:1874-82.

74. Hajek M, Sewell A, Kaech S, Burtness B, Yarbrough WG, Issaeva N. TRAF3/CYLD mutations identify a distinct subset of human papillomavirus-associated head and neck squamous cell carcinoma. Cancer. 2017;123:1778-900.

75. Lechner M, Chakravarthy AR, Walter V, Masterson L, Feber A, Jay A, et al. Frequent HPV-independent p16/INK4A overexpression in head and neck cancer. Oral Oncol. 2018;83:32-7. 
76. Hermida-Prado F, Menéndez ST, Albornoz-Afanasiev P, Granda-Diaz R, Álvarez-Teijeiro S, Villaronga MÁ, et al. Distinctive expression and amplification of genes at 11q13 in relation to HPV status with impact on survival in head and neck cancer patients. J Clin Med. 2018;7:501.

77. Serafini MS, Lopez-Perez L, Fico G, Licitra L, De Cecco L, Resteghini C. Transcriptomics and epigenomics in head and neck cancer: available repositories and molecular signatures. Cancers Head Neck. 2020;5:2.

78. Manterola L, Aguirre P, Larrea E, Arestín M, Gaafar A, Elorriaga $\mathrm{K}$, et al. Mutational profiling can identify laryngeal dysplasia at risk of progression to invasive carcinoma. Sci Rep. 2018;8:6613.

79. Baran CA, Agaimy A, Wehrhan F, Weber M, Hille V, Brunner $\mathrm{K}$, et al. MAGE-A expression in oral and laryngeal leukoplakia predicts malignant transformation. Mod Pathol. 2019;32:1068-81.

80. Liu S, Sang M, Xu Y, Gu L, Liu F, Shan B. Expression of MAGE-A1, -A09, -A11 in laryngeal squamous cell carcinoma and their prognostic significance: a retrospective study. Acta Otolaryngol. 2016;136: 506-13. 